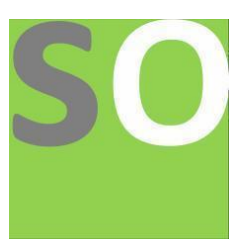

Article title: Taming Runway Climate Change: A Discourse Analysis of the Address of Bahrain Crown Prince at (COP 26) Authors: Yasser A. Gomaa[1]

Affiliations: Department of English Language and Literature, College of Arts, University of Bahrain, Kingdom of Bahrain[1]

Orcid ids: $0000-0003-1503-4337[1]$

Contact e-mail: yasergomaa@gmail.com

License information: This work has been published open access under Creative Commons Attribution License http://creativecommons.org/licenses/by/4.0/, which permits unrestricted use, distribution, and reproduction in any medium, provided the original work is properly cited. Conditions, terms of use and publishing policy can be found at https://www.scienceopen.com/.

Preprint statement: This article is a preprint and has not been peer-reviewed, under consideration and submitted to ScienceOpen Preprints for open peer review.

DOI: 10.14293/S2199-1006.1.SOR-.PPQFVDP.v1

Preprint first posted online: 10 January 2022

Keywords: Climate Change, Discourse Analysis, Climate Change Conference (COP 26), Prince Salman bin Hamad Al Khalifa, Kingdom of Bahrain 


\title{
Taming Runway Climate Change: A Discourse Analysis of the Address of Bahrain Crown Prince at (COP 26)
}

\author{
Yasser A. Gomaa \\ Assiut University, Egypt \\ University of Bahrain, Kingdom of Bahrain
}

\section{Introduction}

Using Fairclough's (1992) three dimensional approach to critical discourse analysis and Dryzek's (2013) concepts of discourse, the article at hand analyses the 511- word address of His Royal Highness Prince Salman bin Hamad Al Khalifa, the Crown Prince and Prime Minister of the Kingdom of Bahrain, at the 26th UN Climate Change Conference (COP 26) held in Glasgow, Scotland on November 2, 2021. Climate change is one of the most pressing issues facing mankind today. As such, it requires swift and drastic action from both global leaders and global corporations, right down to individuals. Since the late nineties, many climate change communication analysts have employed discourse analysis, which is an an interdisciplinary field of inquiry, to unveil the ideological dimensions of stakeholders' beliefs and the dissemination of climate change-related information.

\section{Theoretical framework}

Fairclough (1992, p. 131) states that "Discourse, and any specific instance of discursive practice, is seen as simultaneously (i) a language text, spoken or written, (ii) discourse practice (text production and text interpretation), (iii) sociocultural practice." This statement represents Fairclough's three-dimensional approach to critical discourse analysis, which has been used to analyse HRH's address, together with Dryzek's (2013) views on discourse, which regard discourse as "a shared way of apprehending the world. Embedded in language, it enables those who subscribe to it to interpret bits of information and put them together into coherent stories or accounts" (Dryzek, 2013, p. 9).

\section{Analysis}

HRH commences his address with thanking the President of COP 26 and greeting the audience. He does not mention any particular names in order to arouse the interest of all audience and establish instant rapport with them. His address, which is entirely devoted to climate change, can be described as "going straight to the point" as it avoids stylistic ornament. It is characterised by rarity of figurative language. HRH has relied on nonmetaphorical and truth conditional literality, communicating directly with the audience. This reflects his honesty as well as efficient and utterly dynamic decision-making.

Multifarious syntactic and lexical means have been employed (e.g., the conjunction and is repeated 19 times). Further, the address contains 12 sentences beginning with the subject pronoun "we" to underline the fact that all countries around the globe and he himself have been contributing to hammering out an effective solution to the climate change crisis. Gomaa and Albufalasa (2021, p. 105) argue that "Personal pronouns are employed by the speaker to talk to or about people or things or even about himself." Besides, the first first-person narrative "I" has been used in HRH's address, when he pledges to lead by example and cut Bahrain's emissions by 30 percent by 2035: "I am pleased to announce that Bahrain is committed to reaching net zero by 2060', to stress his personal keenness to resolve the climate change issue, which in turn relates to the core value of the Kingdom of Bahrain that gives top priority to environmental issues. "The combination of (I and You) suggests not merely strong emotion, but also a degree of informality between the speaker and the listener. The informal relation stands among friends, brothers or members of the same family/group" (Gomaa and Albufalasa, 2021, p. 106). In the same connection, in HRH's address, there are three sentences beginning with "We must" structure that 
expresses a verbal process (i.e., process of saying something). Each one of them comprises such elements: speaker, addressee, target, and range/verbiage. That is to say, uttering these sentences constitutes a verbal process in which "We" stands for the speaker, representing the Kingdom of Bahrain. This clearly implies that Bahrain is firmly determined to tackle global warming.

Furthermore, the word "ambitious" is used in: "Today, I am pleased to announce that Bahrain is committed to reaching net zero by 2060 and has set a range of ambitious interim goals to ensure that we proceed without delay here is to emphasize.", to emphasize that the Kingdom of Bahrain accords due attention to resolving the crisis. It also highlights the important position of Bahrain as a world leader in environmental action and reflects its ideologies, core values and commitment to global climate goals as well as the shared responsibility of the international community to protect the environment.

The aforementioned sentence is followed by: (1) "By 2035, we will reduce emissions by 30 percent through decarbonisation and efficiency initiatives and double our deployment of renewables from the targets we set at COP 21", and (2) "Our 2035 targets also include carbon removal solutions by quadrupling mangrove coverage, doubling tree coverage in Bahrain, and directly investing in carbon capture technologies, which we believe is essential." These two sentences are employed to outline the practical steps that will be taken in the near future to tackle climate change. Besides, they mirror the strong patriotic tone of HRH's voice. This has been evident when he shines a positive light on the achievements and efforts of Bahrain to ensure a green future for all. HRH's address clearly conveys to the world that despite the fact that "the kingdom of Bahrain is responsible for just 0.07 percent of global emission," Bahrain is in a race against time to be among the first countries to be environmentally responsible for the wellbeing of the planet, exerting tremendous efforts and spearheading initiatives to reduce emission by 30 percent; notably, decarbonisation and doubling Bahrain's deployment of renewables, investing in carbon capture technologies, doubling tree coverage, and investing in renewable energy.

Furthermore, interdiscursivity has taken place in HRH's address. Jørgensen and Phillips (2002, p. 37) argue that "interdiscursivity occurs when different discourses and genres are articulated together in a communicative event." This is abundantly clear in HRH's address which reflects the climate change discourse that has existed since 1990, and the discourse of research and investment in clean energy. This reflects HRH's ideology as he believes that coming to terms with the problem of climate change is a matter of urgency, and it is possible only through clean energy innovation and investment.

\section{Conclusion}

This article investigates the address of HRH Prince Salman bin Hamad Al Khalifa, the Crown Prince and Prime Minister of the Kingdom of Bahrain, at COP 26, in Glasgow, drawing upon Fairclough's $(1989,1992)$ three dimensional approach to critical discourse analysis and Dryzek's (2013) concepts of discourse. Based on the type of sentences that figure prominently in HRH's address, one can conclude that his address is characterized by a straight forward style that fits well with its framework. It has evoked a sense of global solidarity and reflected HRH's forward-looking vision. His address represents the discourse of climate change and the discourse of world's clean energy investment. Besides, it provides different ways to fight climate change and save the planet. It also commixtures the discourse of long-term commitment in achieving the 1.5 degrees Celsius global warming target with the discourse of innovation and investment in clean energy technologies. On the top of that, it focuses on solutions over barriers, portraying environmental solutions as being beneficial to the economy, connecting environment and economics in a positive way. This has been achieved by proposing solutions that help the economy and, at the same time, the environment. Besides, the Industrial Revolution, which is a significant historical event and a sociocultural factor, has also been mentioned in HRH's address to alert the world to the need for a drastic systemic change, and the need for industries to change. Last but not least, the address 
asserts that resolving the problem of climate change has to be done promptly, and it is possible only through clean energy innovation.

\section{References}

Al Khalifa, S. (2021). Addressat the 26th UN Climate Change Conference (COP 26). [Transcript]. Retrieved from http://www.crownprince.bh/en/media-centre/news/10468/2021/11/2/HRH-the-CrownPrince-and-Prime-Minister-delivers-address-at-COP26.

Dryzek, J. S. (2021). The Politics of the Earth. Oxford: Oxford University Press.

Fairclough, N. (1989). Language and power (2nd ed.). New York: Longman.

Fairclough, N. (1992). Discourse and social change. Cambridge: Polity Press.

Gomaa, Y., \& Albufalasa, M. (2021). Moderating Opposition and Shaping Political Settlement in the US Presidential Speech on the Military Action in Syria: A Critical Discourse Analysis. International Journal of Linguistics, Literature and Translation,4(4), 100-112. https://doi.org/10.32996/ijllt.2021.4.4.11

Jørgensen, M. and Phillips, L. (2002). Discourse Analysis as Theory and Method. Sage: London. 